\title{
Stablization of medical waste incineration fly ash in cement mortar matrix
}

\author{
T. Ahmed*, R. Chowdhury and M. Rahman \\ Department of Civil Engineering, Bangladesh University of Engineering and Technology, Dhaka- 1000, Bangladesh,
}

Received: 20 March 2019

Revised: 10 July 2019

Accepted: 11 November 2019

DOI: https://doi.org/10.3329/bjsir.v55i2.47633

\begin{abstract}
Laboratory experiments were performed to assess the suitability of using medical waste incineration fly ash in cement as a construction material based on the engineering properties of fly ash-cement matrix and the leaching potential of toxic heavy metals from the stabilized mix. Fly ash-cement samples were prepared with different proportions of fly ash $(0 \%, 5 \%, 10 \%, 15 \%$ and $20 \%$ by weight) in the laboratory under controlled conditions. The solidified matrix exhibited a compressive strength from 3950 to 4980 psi when fly ash is mixed in varying proportions. The 28-day compressive strength has been found to decrease with the increase in fly ash content but it meets the minimum requirement of compressive strength for cement-mortar. Soundness test exhibited acceptable results for cement-mortar mixes having up to $15 \%$ fly ash. Final and initial setting times of cement have been found to generally increase with fly ash content. Water requirement (for normal consistency) also increased with the increase in fly ash content in cement. Based on physical properties of the cement-mortar matrix it is recommended that up to $10 \%$ (by weight) medical waste incineration fly ash can be incorporated for producing cement-mortar of optimum quality. Leaching behaviors of several targeted heavy metals ( $\mathrm{As}, \mathrm{Cu}, \mathrm{Ni}, \mathrm{Cd}, \mathrm{Pb}, \mathrm{Hg}$ and $\mathrm{Zn}$ ) were analyzed using Toxicity Characteristics Leaching Procedure (TCLP) of fly ash and solidified fly ash-cement matrix which shows that the leached concentrations of $\mathrm{As}, \mathrm{Cu}, \mathrm{Cd}, \mathrm{Pb}$ and $\mathrm{Zn}$ were reduced by $80.13 \%$, $89.47 \%, 33.33 \%, 23.9 \%$ and $100 \%$ respectively for $10 \%$ fly ash incorporated cement-mortar matrix compared to that of original fly ash. The leached concentrations of heavy metals from the matrix were far below the EPA land disposal limits. These results suggest that the solidified fly ash incorporated cement-mortar matrix can effectively confine and immobilize the heavy metals contained in the fly ash without significantly diminishing the engineering properties of cement-mortar.
\end{abstract}

Keywords: Medical waste; Incineration; Fly ash; Leaching; Heavy metal

\section{Introduction}

Bangladesh, being a developing country, has a rapidly growing urban population. Hospitals, clinics, private individual practitioners, dental clinics, diagnostic centers are growing in urban centres in order to meet the demand for health care services. In Dhaka city the number of health care facilities is almost 1200 and they contribute to the generation of 200 tons medical waste daily on an average, a significant portion of which is toxic (PRISM, 2013). Incineration is a commonly adopted method to neutralize or eliminate medical waste which generally results in decrease in waste volume. However, heavy metals present in the waste can be incorporated in the fly ash at elevated concentrations and inappropriate disposal of fly ash can pose environmental hazards (Tang et al., 2016). Release of heavy metals under certain conditions may lead to contamination of aquifers, surface water or drinking water system (Agamuthu and 
Chitra, 2009). If proper care is not taken during generation, fly ash can also spread out to greater distances by wind and contaminate the air environment. In Bangladesh, there is no specific legislation in the disposal, handling and dumping of medical waste under the Environmental Protection Act, 1995 (Akter, 2000). Although incinerators are operated by medical waste service providers (e.g. PRISM Bangladesh) and some major hospitals in Bangladesh, the incinerated fly and bottom ashes are usually dumped into the landfills without taking into account their potential toxicity and possibility or release of heavy metals into the environment. One technique to contain contamination from toxic substances is to incorporate it in construction materials. Here in this paper, we examine the leachability of heavy metals from medical incineration fly ash and fly ash-stabilized cement mortar mixes. Cement mortars were prepared varying the fly ash proportions and their suitability was assessed based on normal consistency, setting time, compressive strength and soundness. Leaching test of the fly ash-incorporated cement was also carried out to check the effectiveness of stabilization against the leaching of heavy metals in the environment by comparing them with land disposal limit based on established leaching protocols.

\section{Materials and methods}

\section{Collection of fly ash sample}

Fly ash sample was collected from the incinerator of the medical waste treatment facility of Dhaka City Corporation at Matuail which is operated by PRISM Bangladesh. In this facility the medical waste from different health care facilities from Dhaka are received and after separation, chemical disinfection, shredding, autoclaving they are taken into the incinerators. Our fly ash sample was collected from the trash bins at landfill site where incinerated fly ash was dumped.

\section{Preparation of the fly ash sample}

We adopted the methodology proposed by Tang et al. (2016) to process the sample. Fly ash samples were dried in oven for 24 hours to ensure the accurate quality during the experiment. Subsequently they are cooled to room temperature. After cooling the samples were passed through the series of BS standard test sieves (\#4, \#8, \#16, \#30, \#50,\#100, \#200) with the use of mechanical sieve shaker. The portion of the sample retained on \#200 sieve (75 micron) and received on pan ( $<75$ micron) was used for preparing cement mortar.

\section{Characterization of cement mortar-fly ash mixture}

Table I shows the tests that were conducted to characterize the cement and cement-mortar mix with various compositions of fly ash.

\section{Preparation of cement paste}

For normal consistency test, cement paste of 650 grams was mixed with $0 \%, 5 \%, 10 \%, 15 \%$ and $20 \%$ fly ash as a replacement for cement. The required amount of cement was weighed and mixed with water and kept for a duration of 30 secs for absorption. Mixing was done at $(140 \pm 5 \mathrm{rpm})$ for 30 secs with mixer. The mixer kept stopped for 15 secs and then mixer was run at medium speed $(285 \pm 10 \mathrm{rpm})$ and mixed for $1 \mathrm{~min}$. For setting time test, the sample was prepared as described for normal consistency test. The amount of water added to cement was the amount of water determined from normal consistency test. The cement paste sample was kept undisturbed for $30 \mathrm{~min}$ in a moist room.

\section{Preparation of cement mortar mix}

One part of cement was mixed with 2.75 gm of graded standard silica sand conforming to the specification of C778-02. A water-cement ratio of 0.485 was used. $700 \mathrm{gm}$ cement paste (with $0 \%, 5 \%, 10 \%, 15 \%, 20 \%$ fly ash as a replacement of cement) was mixed with $1925 \mathrm{gm}$ of sand for preparation of the sample. Immediately upon completion of molding, the test specimens were placed in a moist room for 20 to 24 hours with the upper surfaces exposed to the moist air but protected from getting wet through water. Then the specimens were immersed in saturated lime water in storage tanks constructed of non-corroding materials. For compressive strength test, three specimens from each batch of mortar were prepared for 3 days, 7 days and 28 days test. So total 9 mortar specimens were made with each of the proportions of fly ash $(0 \%, 5 \%, 10 \%, 15 \%, 20 \%)$.

\section{Preparation of specimens for soundness test}

For soundness test, the compositions for different samples were as shown in Table II. One single molded cement bar was made for each variation of the fly ash composition. So, total 5 specimens were made for the test.

\section{Heavy metal determination}

Sample preparation for heavy metal analysis was carried out according to EPA 3050B and the concentration of heavy metals was determined using Atomic Absorption Spectrophotometer (AAS). After collection of incinerated fly ash sample, some portion of fly ash samples were dried in a vacuum oven at $105^{\circ} \mathrm{C}$ until constant weight, lightly ground for homogenization and passed through $2-\mathrm{mm}$ sieve. For heavy metal analysis, sample preparation was carried out according to EPA 3050B with a slight variation. $5 \mathrm{gm}$. of dried sample was digested with acid $\left(\mathrm{HNO}_{3}: \mathrm{HCl}=1: 3\right.$ volume ratio) for 24 hours. After adding 350-400 ml distilled 
Table I. Test names and test method for cement and cement-mortar mix

\begin{tabular}{lll}
\hline \multicolumn{1}{c}{ Name of the Tests } & Test Method & \multicolumn{1}{c}{ Test for } \\
\hline Determination of normal consistency & ASTM C187 & Cement \\
Determination of setting time & ASTM C191-08 & Cement \\
Compressive strength & ASTM C150-12 & Cement-mortar \\
Soundness & ASTM C1038-01 & Cement-mortar \\
Total Heavy Metal & EPA 3050B & Fly ash/cement-mortar \\
Toxicity Characteristics Leaching Procedure (TCLP) & USEPA 1311 & Cement-mortar \\
\hline
\end{tabular}

Table II. Compositions for different samples for soundness test

\begin{tabular}{lcccc}
\hline Fly ash percentage & Cement $(\mathrm{gm})$ & Fly ash $(\mathrm{gm})$ & Water(gm) & Sand(gm) \\
\hline $0 \%$ & 300 & 0 & 145.5 & 825 \\
$5 \%$ & 285 & 15 & 145.5 & 825 \\
$10 \%$ & 270 & 30 & 145.5 & 825 \\
$15 \%$ & 255 & 45 & 145.5 & 825 \\
$20 \%$ & 240 & 60 & 145.5 & 825 \\
\hline
\end{tabular}

water, sample was boiled for 2.5 hour and a $500 \mathrm{ml}$ solution was prepared. Then, solution was filtered through a $0.45 \mu \mathrm{m}$ filter paper and filtrate was collected to determine the concentration of seven heavy metals ( $\mathrm{As}, \mathrm{Pb}, \mathrm{Cd}, \mathrm{Cr}, \mathrm{Ni}, \mathrm{Cu}$, and $\mathrm{Zn}$ ) by using Atomic Absorption Spectrophotometer (AAS) (Shimadzu AA 6800)

\section{Toxicity characteristics leaching procedure (TCLP)}

According to Tsiridis et al. (2006), a commonly used test for the determination of the leaching characteristics of fly ash is the Toxicity Characteristic Leaching Procedure (TCLP Method 1311) established by the US Environmental Protection Agency (USEPA, 1992). This procedure provides a uniform method to compare the tendency of inorganic elements to leach out from fly ash samples into moderate-to-highly acidic aqueous environments. During the TCLP test, constituents are extracted from the waste to simulate leaching actions that occur in landfills. If the concentration of the toxic constituents exceeds the regulatory limit, the waste is classified as hazardous. TCLP tests were performed following the USEPA 1311 for two types of samples: (1) original fly ash sample (2) Cube specimen containing $10 \%$ fly ash.

\section{Results and discussion}

Normal consistency

Figure 4 shows that normal consistency increases with the increase of percentage of fly ash. Up to $15 \%$ of fly ash the normal consistency value remains close to the ASTM C150 standards range of $20 \%$ to $30 \%$ but at $20 \%$ of fly ash the normal consistency value goes beyond the limit. Kumar et al. (2016) studied the effect of cement properties with the partial replacement of biomedical waste fly ash and showed that water requirement increased with the increase in fly ash percentage and workability of concrete decreased with the increase in fly ash content. Since the fly ash is lighter than cement it occupies more volume than cement on equal weight basis. So more water is needed for lubrication and therefore the normal consistency increases. Our test results agree with the behavior of cement with fly ash as previously showed by Kumar et al. (2016).

\section{Setting time}

In this study the change in the setting time with the increase in fly ash percentage was observed. The limit of the standard values of the initial and final setting time is shown in table III. The variation in the setting time with the increased percentage of fly ash is shown in figure 5. From the graph it is evident that there is a decrease in initial setting time when $5 \%$ fly ash is added and then initial setting time increases with increase of fly ash. It can also be seen that the final setting time increases significantly with the increase in fly ash up to $5 \%$. From $5 \%$ to $20 \%$, there is no appreciable change of final setting time. With $5 \%$ addition of fly ash, final setting time goes beyond the maximum limit of ASTM C150-12 specification standard of $375 \mathrm{~min}$. Augustine (2016) observed that the initial and final setting times for $20 \%$ ash content were 300 and $985 \mathrm{~min}$ respectively. In this study, the 


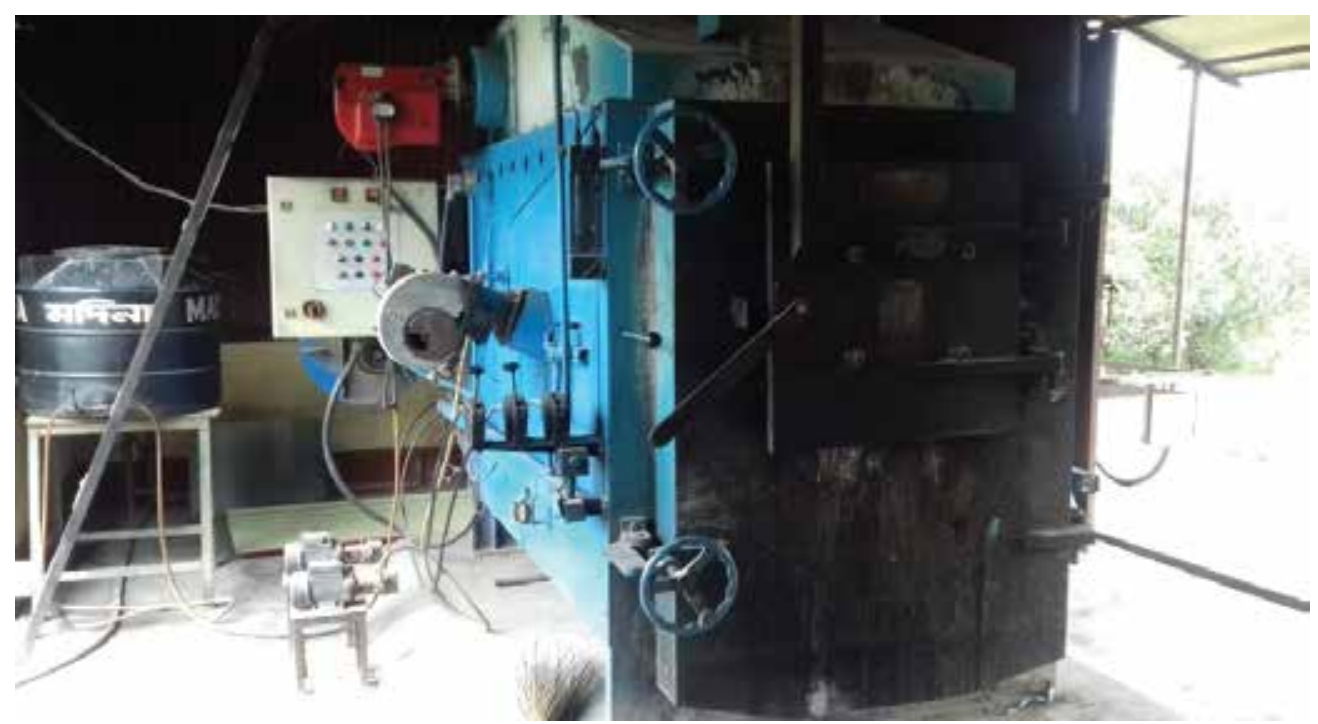

Fig. 1. Incinerator of PRISM Bangladesh at Matuail landfill site
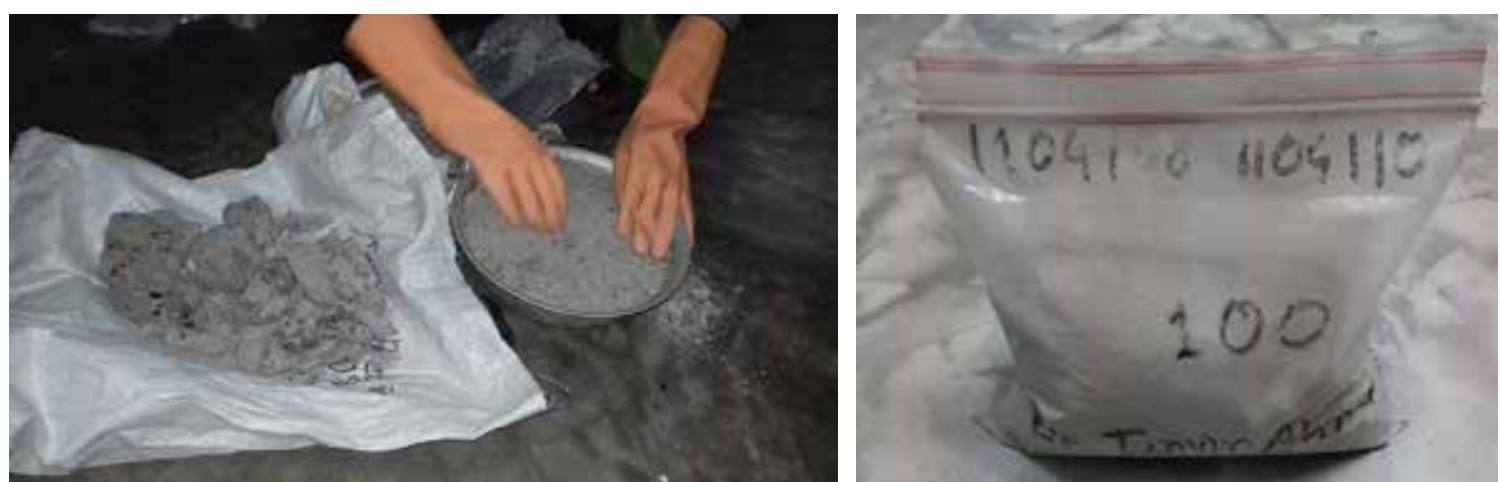

Fig. 2. Separation of large particles from incineration fly ash manually and storage of the prepared sample in zip-lock bags
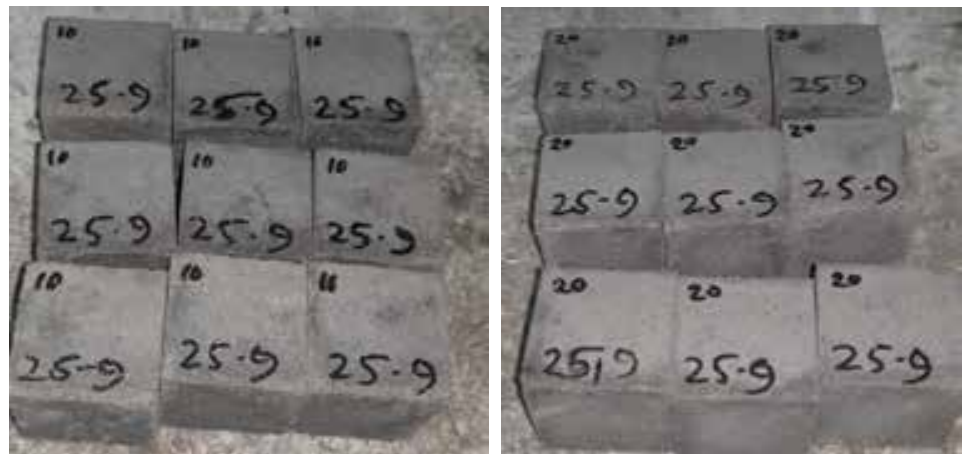

Fig. 3. Cement-mortar cube specimens consisting of $10 \%$ and $20 \%$ fly ash

initial and final setting time of our experiment for $20 \%$ fly ash are 250 and $545 \mathrm{~min}$ respectively. It is evident from the study that the introduction of fly ash to a concrete mix design could lengthen the overall hydration period. The presence of $\mathrm{Cu}, \mathrm{Pb}$ and $\mathrm{Zn}$ compounds are set-inhibiting and could have contributed to the increase in setting time (Zain et al., 2004). For highway construction, the delays of setting time may be considered advantageous especially for hot weather concreting to keep the concrete workable for a long time. 


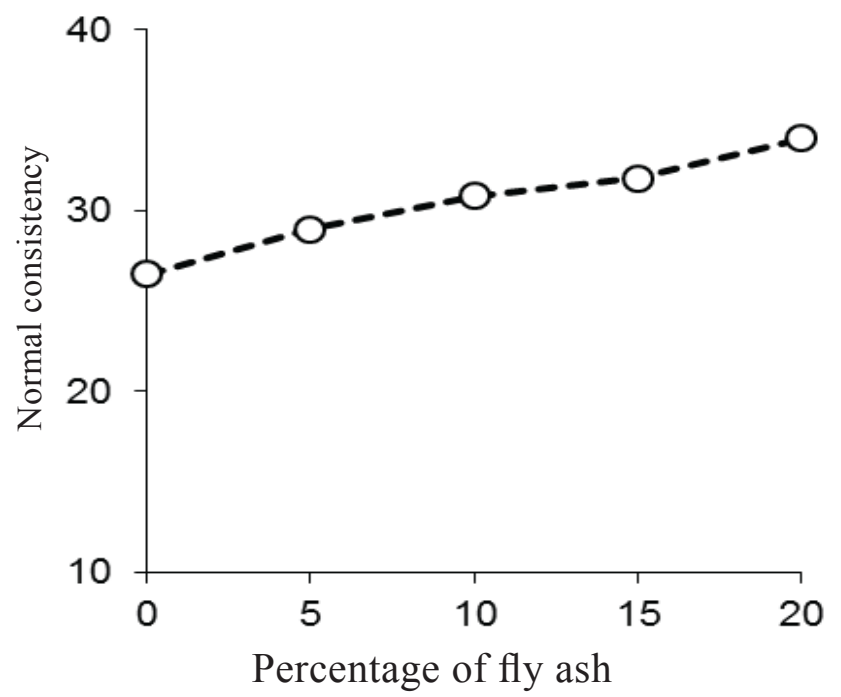

Fig. 4. Relationship between normal consistency and percentage of fly ash

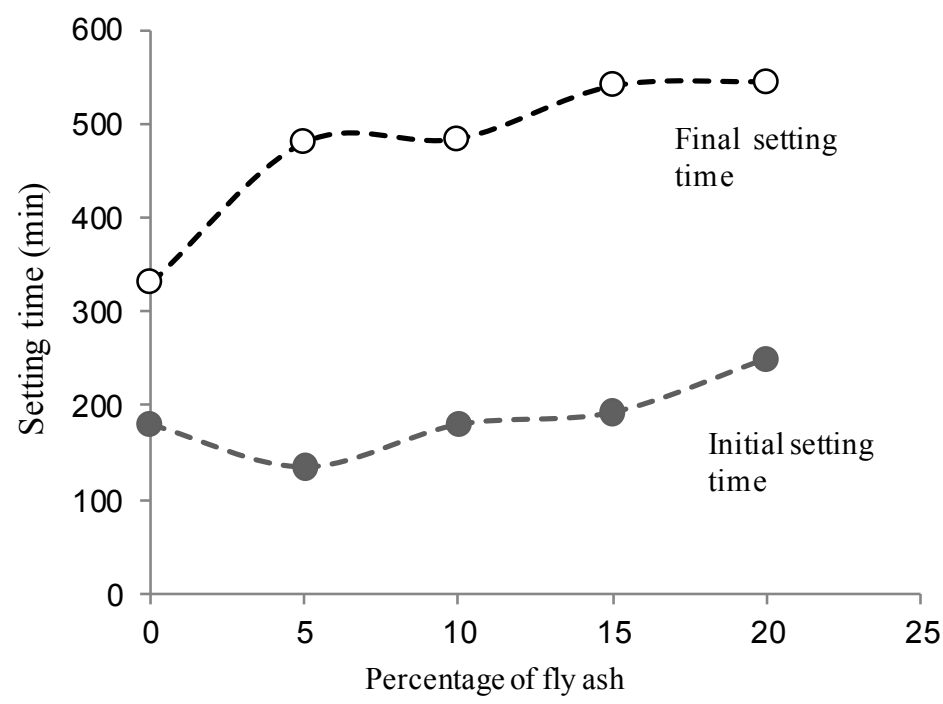

Fig. 5. Relationship between setting time and fly ash content

\section{Compressive strength}

Table IV shows the variation of compressive strength with the increase in fly ash proportions. Compressive strength (average of three samples) vs. no. of days in Figure 6 shows that up to $15 \%$ addition of fly ash the strength values of 3,7 and 28 days fulfill the minimum ASTM C150-12 requirements for compressive strength for the corresponding time periods. But for $20 \%$ addition of fly ash, the strength value of 28 days is 3950 psi which fails to meet the minimum requirement of $4060 \mathrm{psi}$. In general, the 28-day strength has been found to decrease with increased fly ash content.
Although the 3-day and 7-day strengths for cement mortars having $5 \%$ and $10 \%$ fly ash are very much comparable with the control specimen ( $0 \%$ fly ash), the addition of $15 \%$ and $20 \%$ fly ash has reduced the compressive strength significantly. The reason for the decrease in compressive strength with the increase in fly ash beyond a certain limit is that the heavy metals present in the ash such as $\mathrm{Pb}, \mathrm{Cu}$, and $\mathrm{Cr}$ could have inhibited the solidification of the matrix (Agamuthu and Chitra, 2009). Singh et al. (2016) conducted similar tests with fly ash-incorporated concrete and observed that compressive strength of concrete for 7 and 28 days attains a maximum value for $5 \%$ to $10 \%$ replacement by fly 


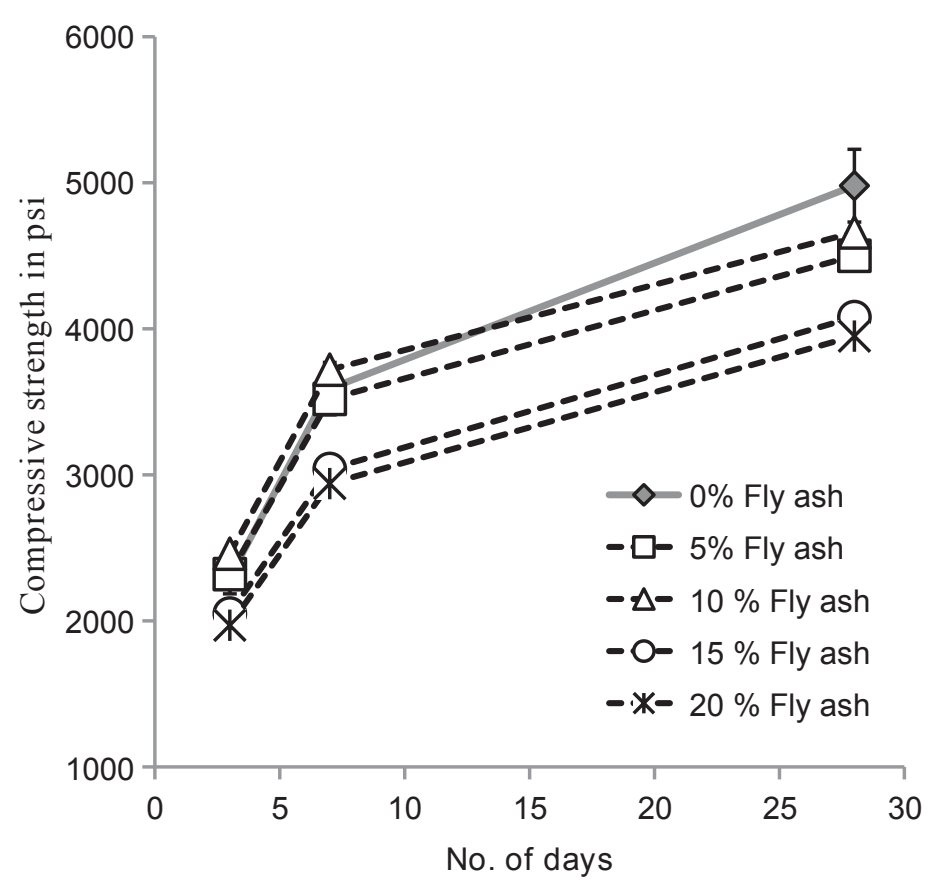

Fig. 6. Change in compressive strength with the increase in fly ash percentages for 3,7 and 28 days

ash. Agamuthu and Chitra (2009) showed a decrease in compressive strength with the increase in fly ash proportions which follows the similar trend found in these experiments particularly for fly ash content in excess of $10 \%$.

\section{Soundness test}

Soundness is an important parameter which signifies that cement should not undergo any significant volume change after setting. According to ASTM C150, a maximum mortar bar expansion of 0.02 percent is specified for all types of Portland cement. From our results shown in Table V, mortar bars having $0 \%$ and $10 \%$ of fly ash showed volume shrinkage while mortar bar having 5\% fly ash did not exhibit any volume change. Mortar bar of $15 \%$ fly ash has expanded within the maximum allowable limit but mortar bar of $20 \%$ fly ash has shown an expansion exceeding the maximum ASTM C150 limit. The amount of mortar-bar expansion that was obtained according to ASTM C1038 method is related to the amount of sulfate in the cement and excessive expansion was observed because it contained too much sulfate. According to test results, the amount of sulfate increases with increasing of fly ash content and excessive expansion occurs for $20 \%$ fly ash due to high amount of sulfate. Y1lmaz and Olgun (2008) investigated the effects of low-calcium fly ash on cement and mortar and the replacement of Portland cement by low calcium fly ash ranging from 5\% to $40 \%$ reduced expansion compared to control cement paste without fly ash. This indicates that unless the sulfate content is controlled, addition of excessive fly ash will generally cause an expansion. In our studies the suitable proportion of medical waste incineration fly ash has been found to be $5 \%$ to $15 \%$ from the soundness test criteria. The soundness test results obtained from this experiment are given in Table V.

\section{Heavy metal content in fly ash}

Heavy metal determination test was conducted on raw fly ash sample in order to understand their relative abundance. The selected heavy metal concentrations for the sample found in the fly ash in this study and their comparison with several international regulatory standards are shown in Table VI. It allows the arrangement of the heavy metals from higher to lower concentrations as: $\mathrm{Zn}>\mathrm{Cu}>\mathrm{Pb}>\mathrm{Cr}>\mathrm{Ni}>\mathrm{As}>\mathrm{Cd}$. The present study found that the concentration of $\mathrm{As}, \mathrm{Cr}, \mathrm{Pb}, \mathrm{Ni}$ were well below the permissible limit of Bangladesh, China

Table III. Initial and final setting time test result for various percentages of fly ash

\begin{tabular}{lrrrrrll}
\hline \% of fly ash & 0 & 5 & 10 & 15 & 20 & ASTM C150-12 & IS 4031 (part 5) \\
\hline Initial setting time (min) & 180 & 135 & 180 & 193 & 250 & $45(\min )$ & $30(\min )$ \\
Final setting time (min) & 330 & 480 & 484 & 540 & 545 & $375(\max )$ & $600(\max )$ \\
\hline
\end{tabular}


Table IV. Average values of the compressive strength for different fly ash proportions

\begin{tabular}{lccccccc}
\hline Percentage of fly ash & & 0 & 5 & 10 & 15 & 20 & $\begin{array}{c}\text { ASTM C150-12 } \\
\text { requirement }\end{array}$ \\
\hline Average & 3 days & 2300 & 2320 & 2460 & 2050 & 1970 & 1740 \\
Compressive & 7 days & 3590 & 3520 & 3720 & 3040 & 2940 & 2760 \\
Strength (psi) & 28 days & 4980 & 4500 & 4660 & 4080 & 3950 & 4060 \\
\hline
\end{tabular}

Table V. Soundness test results of cement-mortar cubes having different proportions of fly ash

\begin{tabular}{lcc}
\hline Amount of fly ash & Percentage of change & Comment \\
\hline $0 \%$ & 0.004 & Shrinkage \\
$5 \%$ & 0.000 & No change \\
$10 \%$ & 0.008 & Shrinkage \\
$15 \%$ & 0.004 & Expansion \\
$20 \%$ & 0.052 & Expansion \\
\hline
\end{tabular}

and USA Land Disposal Restriction Limits. The concentration of $\mathrm{Cd}$ and $\mathrm{Cu}$ are well below the Bangladesh and USEPA limit but exceeds the SEPAC (State Environmental Protection Administration of China) by 2 times. The concentration of $\mathrm{Cu}$ in the fly ash is about two times higher than the SEPAC limit. The concentration of $\mathrm{Zn}$ satisfies with the USEPA standard but it is more than 2 times higher than the permissible limit in Bangladesh and SEPAC limit.

\section{Toxicity characteristics leaching procedure (TCLP)}

TCLP test was carried out on the raw fly ash sample and on the cement-mortar cube mixed with $10 \%$ fly ash which was cured over 28 days. Since, the engineering properties of cement mortar with $10 \%$ utilization of fly ash provides

Table-VI. Concentration of heavy metals in the fly ash sample comparing with standards limit

\begin{tabular}{lccccccc}
\hline Parameters & \multicolumn{7}{c}{ Heavy metals in the sample $(\mathrm{mg} / \mathrm{kg})$} \\
\cline { 2 - 8 } & $\mathrm{As}$ & $\mathrm{Cr}$ & $\mathrm{Pb}$ & $\mathrm{Cd}$ & $\mathrm{Ni}$ & $\mathrm{Cu}$ & $\mathrm{Zn}$ \\
\hline Sample & 6.72 & 16.4 & 42.4 & 1 & 13.5 & 181.2 & 610.7 \\
Permissible limit in Bangladesh & 40 & 100 & 100 & 1.5 & 50 & 60 & 200 \\
SEPAC limit in China & - & 250 & 350 & 0.6 & 26600 & 100 & 300 \\
USEPA limit & 75 & 3000 & 840 & 85 & 420 & 4300 & 7500 \\
\hline
\end{tabular}

Table VII. Result of concentration of in standard TCLP leaching test of leachates from fly ash sample and cube sample mixed with $10 \%$ fly ash and comparison with Land Disposal Restrictions Limits (LDR)

\begin{tabular}{lccccccc}
\hline Heavy metal & $\mathrm{As}$ & $\mathrm{Cu}$ & $\mathrm{Ni}$ & $\mathrm{Cd}$ & $\mathrm{Pb}$ & $\mathrm{Hg}$ & $\mathrm{Zn}$ \\
\hline Raw fly ash value (mg/l) & 0.0297 & 0.057 & 0 & 0.006 & 0.364 & 0 & 0.653 \\
10\% Cube mortar (controlled sample) value (mg/l) & 0.0059 & 0.006 & 0.015 & 0.004 & 0.277 & 0 & 0 \\
\% of reduction & 80.13 & 89.47 & - & 33.33 & 23.90 & 0 & 100 \\
EPA Land Disposal Limit (LDR) (mg/l) & 5 & - & 11 & 0.11 & 0.75 & 0.25 & 4.3 \\
\hline
\end{tabular}


optimum values for the normal consistency, initial and final setting time, compressive strength and soundness test, $10 \%$ fly ash mixed mortar was considered for this test. Table VII shows that the heavy metal concentration in raw fly ash and mortar cube having $10 \%$ fly ash are found to be under the EPA Land Disposal Limit (LDR). This indicates that there would be low risk of ground water contamination by leaching action. In this case, the stabilization of fly ash with the cement mortar reduces the leaching tendency of heavy metal compared to the raw fly ash. Arsenic content reduces by $80.13 \%$; Copper reduces by $89.47 \%$; Cadmium reduces by $33.33 \%$; $\mathrm{Pb}$ reduces by $23.90 \%$ and Zinc reduces by $100 \%$.

\section{Conclusions}

We have shown that heavy metals present in fly ash can be successfully immobilized when it is incorporated in cement-mortar matrix albeit having slightly detrimental effects on its engineering properties such as workability, setting times, soundness and compressive strength. But cement with $10 \%$ fly ash can still have desirable engineering properties as per ASTM specifications of cement and cement-mortar matrix. Therefore, medical waste incineration fly ash incorporation into cement appears to be a promising avenue for waste management and successful recycling of waste in the construction material.

\section{Acknowledgement}

Authors would like to render their special gratitude to the officials of PRISM medical waste management foundation who assisted in the process of sample and other data collection. In this regard, the authors are grateful to Khondkar Anisur Rahman, Executive Director of PRISM foundation. The authors also acknowledge the heartiest co-operation and assistance of all the staffs of Concrete Laboratory, Environmental Engineering and Geotechnical Engineering Laboratory of BUET during different stages of experiments.

\section{References}

Agamuthu P and Chitra S (2009), Solidification/Stabilization disposal of medical waste incinerator fly ash using cement, Malaysian Journal of Science 28(3): 241-255.

Akter N (2000), Medical waste management: A review, Environmental Engineering Program, School of Environment, Resources and Development, Asian Institute of Technology, Thailand. 1-25. DOI: $10.1111 /$ rec. 12028

Augustine U E, (2016), Hospital Ash Waste-Ordinary Portland Cement Concrete, Science Research 4(3): 72-78.
Kumar U, Srivastava V and Singh AK (2016), Suitability of biomedical waste ash in concrete, International Journal of Engineering and Technical Research 5(2): 2454-4698.

PRISM (2013), Survey on Quantitative and qualitative assessment of medical waste generation and management in Dhaka North City Corporation and Dhaka South City Corporation, January, 2013. Available at: http://pbf.org.bd/ wp-content/uploads/ 2014/01/Survey-on- Quantitative- qualitative-assessmentofmedical-waste-generation-and-managemant-inDNCC-DSCC.pdf.

Singh AK, Srivastav V and Kumar U (2016), Biomedical waste ash in concrete: an experimental investigation, International Journal of Innovative Research in Science, Engineering and Technology 5(6): 2347-6710.

Tang Q, Liu Y, Gu F and Zhou T (2016), Solidification/ stabilization of fly ash from a municipal solid waste incineration facility using Portland cement, Hindawi Publishing Corporation.

Tsiridis V, Samaras P, Kungolos A and Sakellaropoulos GP (2006), Application of leaching tests for toxicity evaluation of coal fly ash, Environmental toxicology 21(4): 409-416. DOI: 10.1002/tox.20187

USEPA (1992), Toxicity Characteristics Leaching Procedure (TCLP), USEPA Method 1311, Publication SW 846. Available at: https:/www.epa.gov/ epaoswer/ hazwaste/ tests/pdfs/1311.pdf.

Yilmaz B and Olgun A (2008), Studies on cement and mortar containing low-calcium fly ash, limestone, and dolomitic limestone, Cement and Concrete Composites 30(3): 194-201. DOI: 10.1016/j.cemconcomp.2007.07.002

Zain MFM, Islam MN, Radin SS and Yap SG (2004), Cement based solidification for the safe disposal of blasted copper slag, Cement and Concrete Composites. 26(7): 845-851. DOI: 10.1016/j.cemconcomp.2003.08.002 